\title{
Rethinking the German nation as German Dasein: Intellectuals and Heidegger's philosophy in contemporary German New Right nationalism
}

This is a preliminary version of an article whose final and definite form will be published in The Journal of Political Ideologies, (C) Informa UK Limited, trading as Taylor \& Francis Group.

\section{Julian Göpffarth}

European Institute, London School of Economics and Political Science

Address: 30-32 Dresden Road, N19 3BD London

Email: j.j.gopffarth@1se.ac.uk

Phone: 07743540890

Twitter: @JGopffarth

LinkedIn: Julian Göpffarth 


\section{Abstract}

Most scholarship on far-right parties focuses on populism while largely ignoring the role of intellectualism. Disregarding the increasing support by well-educated voters, much of this literature appears to presume that populism and intellectualism in the far-right are separate rather than complementary phenomena. Against this view, this article uses Skinner's concept of 'innovating ideologists' to explore the role of Heideggerian philosophy in the interplay between German New Right (GNR) intellectualism and Alternative für Deutschland (AfD) populism. To do so, Heidegger's conception of 'people' is outlined before turning to the GNR's use of these concepts in articles, books and speeches, by both GNR intellectuals and leading AfD members. The analysis shows that GNR and AfD actors refer to Heideggerian philosophy both in the context of intellectual circles and to wider audiences to legitimise an exclusive idea of nationhood based not on the illicit idea of race but on a more acceptable idea of history. The findings suggest that intellectualism and populism in the German far-right are closely connected. The article concludes that neglecting GNR intellectualism means underestimating the GNR's and AfD's capacity to bring about social change.

Keywords: Germany; New Right; Heidegger; Nationalism; Populism; Intellectuals; AfD

\section{Introduction}

Since far- and radical-right parties had their first electoral successes in Europe in the 1980s, the literature on them has burgeoned. With the rise of the Front National in France and more recently the Alternative für Deutschland (AfD) in Germany, the amount of academic research has further increased, lately focusing on far-right populism. ${ }^{1}$ While many scholars of what today is commonly called the 'populist far/radical right' have examined socio-economic and political demand-side factors, ${ }^{2}$ those looking at the supply side and far-right ideology ${ }^{3}$ have largely ignored the role of intellectualism. Populism is 
mainly conceptualised as a 'thin ideology" that does not 'possess the same level of intellectual refinement and consistency as "thick" or "full" ideologies' and is centred on the opposition of a 'pure people' against a 'corrupt elite'. ${ }^{5}$ On this basis, the AfD has been described as a populist anti-elitist far-right party. ${ }^{6}$ I do not contest this ideational conceptualisation of populism. Rather, I argue that the emphasis on the populist element has led to a neglect of the role of intellectual elites inside the 'populist far/radical right'. Implicit in much of the literature is the assumption that intellectualism is separate from and not complementary to far-right populism. Focusing on the contemporary German New Right (GNR), I aim to show how intellectualism and populism are intertwined and argue against the widespread view that 'simplistic populism' and 'complex philosophy' are separate or even antagonistic phenomena. To do so, I draw on six months of research in the $\mathrm{GNR}^{7}$ and analyse textual evidence of the use of Heideggerian philosophy by GNR intellectuals, AfD politicians and social movements to frame and legitimise their political language.

The focus will be on how Heidegger's notions of nation and Volk (people) form a resource for a rethinking of German nationhood that, in turn, forms an integrative conceptual basis for GNR civil society networks linking 'populist' and 'intellectual' political actors. Drawing on Skinner's concept of 'innovating ideologists' ${ }^{8}$ I will argue that GNR intellectuals use Heidegger's vernacular terminology to legitimise an exclusive nationalism ${ }^{9}$ based not on the illicit idea of race but on history. (Re)conceptualising an exclusive nationalism in such a way may allow them to appeal to greater audiences and intellectual circles alike. The focus on Heidegger is not to suggest that he is the only ideological resource, but that he is one central one. Equally, the aim of this paper is not to 
verify whether the GNR and AfD use Heidegger correctly but to examine why philosophy plays a role at all in a 'populist milieu', and why Heidegger specifically.

Section 1 therefore defines the GNR and discusses the place of philosophy in the literature on the far/radical right. Quentin Skinner's concept of 'innovating ideologists' is introduced to frame the subsequent analysis of GNR intellectual discourse. Instead of positioning the 'intellectual' GNR against and the 'populist' far-right AfD, the GNR is conceptualised as a civil society network including the AfD. Here forms of nationalism may be elaborated in close interactions between intellectuals, AfD and street movements transcending the populism-intellectualism divide. Section 2 discusses Heidegger's philosophy, exposing the parts that lend themselves to appropriation by the GNR. Heidegger's notions of nation and Volk will be sketched out. Special focus will be put on his concept of Dasein, the role of history, care and being-towards-death in the constitution of a Volk, and 'technocratic modernity' (Gestell) as a 'threatening other' to the authentic Dasein of a Volk. ${ }^{10}$ Focusing on GNR hubs in Schnellroda, Dresden and Berlin, the last two sections examine the use of Heidegger's concepts in articles, speeches and statements by GNR intellectuals, activists and AfD politicians since the climax of the so-called PEGIDA protests in 2015. ${ }^{11}$

\section{The New Right, intellectuals and philosophy}

\section{The German New Right as a civil society network}

The emergence of the GNR can be traced back to the 1960s. ${ }^{12}$ As a new right it attempted to dissociate itself from an old right largely associated with National Socialism (NS).

Except for some electoral success of parties close to the GNR in the 1980s and 1990s and 
a series of publications that reached a broader audience after reunification, ${ }^{13}$ the impact of the GNR has remained rather limited. ${ }^{14}$ In his analysis of the GNR in the 1990s JanWerner Müller sees the main reasons for the GNR's failure in a lack of ideological innovation, institutional support and its inability to dissociate itself from the old right while keeping the distance to the conservative CDU. ${ }^{15}$ However, since the foundation of the AfD and the so-called refugee crisis in 2015, GNR output has increased, an institutional infrastructure has emerged, and its ideology been updated. Alongside 'veterans' of the GNR, new central actors have emerged, including former representatives of established parties and media.

I define the GNR as a network at the conjunction of conservatism and right extremism, ${ }^{16}$ opposing the idea that there are two distinct types of far-right politics: 'narrow-minded party politics' and an 'intellectually free-floating phenomenon detached from pragmatic political concerns' ${ }^{17}$ Instead, I see large parts of the AfD as important actors in a GNR civil society network - a communicative space in which illiberal and nationalist ideas are elaborated and thrive. ${ }^{18}$ This network mirrors the two wings that can roughly be discerned inside the AfD: an ordoliberal one focusing on economic national interests and a national conservative one focusing on the reassertion of a national culture. ${ }^{19}$ Despite political differences, they share a nationalist focus, and the boundaries between the camps are often fluid.

The GNR network is carried by think tanks (Institut für Staatspolitik (IfS), Bibliothek des Konservatismus (BdK)), publishing houses (Antaios, Manufactum), social movements (PEGIDA in Dresden, Zukunft Heimat in Cottbus, Frauenmarsch in Berlin), youth organisations (Identitarian Movement), journalists, politicians and intellectuals. 
Besides the think tanks, important forums of exchange are a plethora of more established and new press publications almost exclusively aimed at an intellectual audience. The IfS and Antaios are led by Götz Kubitschek, probably the most visible figure in the contemporary GNR. Seated in a medieval mansion in the tiny eastern German village of Schnellroda, they represent an alternative nationalism focusing on Heimat (homeland) and nature, mingling intellectualism with street activism and close links to the Identitarian Movement. With its isolated headquarters, it underlines its distance from party politics and its intellectual independence. Their bi-monthly Sezession has been published since 2003 and, together with its blog version, has developed into a central GNR publication. Tichys Einblick, on the other hand, represents the more moderate, ordoliberal faction of the AfD and emerged in 2016 out of an internet blog by a former Focus journalist. Tumult started as a far-left publication in the late 1970s and was relaunched in 2013. It reaches mainly an academic audience and is published in Dresden, a city that has developed into another central GNR hub. Another increasingly influential magazine is $C A T O$, published since 2017 under the influence of GNR veteran Karl-Heinz Weißmann and the BdK. Seated in the bourgeois Berlin neighbourhood of Charlottenburg, BdK and CATO embody a GNR rooted mainly in a western German tradition, not as distant from Germany's political institutions as the IfS or Tumult. As such, it is close to the equally Berlin-based newspaper Junge Freiheit and its editor Dieter Stein. Established in 1996, it is aimed at a broader audience.

Besides these print products, blogs are increasingly popular among an intellectual readership. Michael Klonovsky's (also a former Focus journalist) blog Acta Diurna, David Berger's (former editor-in-chief of the gay periodical MÄNNER) Philosophia 
Perennis and Vera Lengsfeld's (CDU ${ }^{20}$ politician) Achse des Guten are only some of the most important blogs. Epoch Times and PI News are equally recent 'alternative' online media but are aimed at a more popular audience. An interesting case is Compact. Founded by the former far-left Jürgen Elsässer, it is present at all PEGIDA demonstrations and has a strong presence on- and offline. Its articles range from populist news to interviews and articles with and on intellectuals.

These are only some of the central actors and platforms in a constantly growing network, equally carried by a large number of social media accounts, social activism and festivals such as the Kyffhäuser and Wartburg Festivals. Common actions between the different actors are often organised and financed by the network Ein Prozent founded by Kubitschek and Elsässer. This nationwide network is complemented by local private salons where GNR protagonists present and discuss their newest publications.

Overall, it is not an exaggeration to say that the GNR has established an alternative civil society network ${ }^{21}$ with its own public sphere that is increasingly visible, not only through new publications but also in a surge of activism. Schnellroda, Berlin and Dresden can be seen as central hubs of exchange between street activists, intellectuals, AfD politicians and different factions of GNR nationalism. Even if these publications cover different GNR currents, the networks between them are dense, and authors write interchangeably for them. What unites these different groups is the conviction that German culture is in a decline reversible only through a national reassertion against a Holocaust-related culture of guilt, ${ }^{22}$ Islam and immigration, ${ }^{23}$ neglect of Germany's own culture, ${ }^{24}$ moral universalism ${ }^{25}$ or the EU. ${ }^{26}$ 


\section{Philosophy, intellectuals and populism in the GNR}

Despite these links, intellectualism and philosophy play a marginal role in the populist far-right literature. Arguably, this is partly because much of the current research draws its insights from party manifestos or speeches given by prominent party members. Less in focus is GNR intellectualism as a potential factor in the increased acceptance of populist far-right ideology by the mainstream. The GNR is mainly regarded as a separate cultural phenomenon ${ }^{27}$ whose influence on populist far-right parties is doubted. ${ }^{28}$ In the case of Germany, this separation can be challenged for two reasons.

First, on the supply side, the national-conservative AfD wing has gained importance since the party's foundation in 2013. National-conservative AfD members far outnumber more moderate members in the German parliament. ${ }^{29}$ The AfD has developed from a party with an economic ordoliberal focus into an increasingly nationalistic party. ${ }^{30}$ Even if political differences persist, the common ground is a nationalist framing of politics as well as an attempt to redefine German identity in an overtly nationalist way. This redefinition relies on intellectual concepts and an alternative political language. As a consequence, strong links between the 'populist' AfD and the 'intellectual' GNR have developed. Many AfD politicians are guests at GNR events while some GNR intellectuals are party members and/or regularly present at party meetings. Central here are the BdK and the IfS, the latter of which has spread its influence into the core of German democracy. In June 2018, the IfS had its first appearance in the buildings of the Bundestag with a presentation of the IfS's 'scientific director' Erik Lehnert. ${ }^{31}$ Like many authors and protagonists of the IfS, the BdK, Tumult or CATO, Lehnert is a parliamentary assistant for an AfD MP. Equally, Ein Prozent recently held its first workshop in the 
Bundestag upon invitation by the AfD. ${ }^{32}$ The most influential intellectual expression of support of core AfD but also PEGIDA claims so far has been the Erklärung 2018 signed by a wide range of old and new GNR protagonists. ${ }^{33} \mathrm{~A}$ look at the names on the petition shows the width of the GNR coalition bringing together GNR (Karl-Heinz Weißmann, Dieter Stein) and former New Left intellectuals (Frank Böckelmann, Henryk M. Broder) as well as former representatives of established media and parties (Matthias Matussek, Eva Herman, Vera Lengsfeld, Thilo Sarazzin). Equally important is the fact that the AfD now officially allows its members to cooperate with PEGIDA ${ }^{34}$ and is openly present at demonstrations in Dresden and other cities. AfD's reach into civil society is further institutionalised by the Desiderius-Erasmus-Stiftung, recently confirmed as the official party foundation. Its aim is to break the dominating 'leftist ideology' through a 'cultural revolution' ${ }^{35}$ The board of trustees is made up of a variety of cultural and academic actors, including central GNR figures such as Karl-Heinz Weißmann and David Berger (see above).

A second reason lies on the demand side. The AfD appeals to well-educated voters who, at least in part, can be considered local and national cultural elites, often with rather well-off middle-class backgrounds. ${ }^{36}$ This holds equally true for such social movements as PEGIDA. ${ }^{37}$ Contrary to what the term 'populism' suggests, AfD voters are not exclusively a group of uneducated voters left behind, rising against elites and looking for easy answers. At least in the case of Germany, a rigid separation between 'far-right populism' and 'GNR intellectualism' thus seems difficult to uphold and more reflects methodological convenience than reality. 


\section{GNR intellectuals as 'innovating ideologists'}

The common perception of populism and intellectualism as antagonistic can be interpreted as a vision of politics that, according to Skinner, dismisses the role of 'professed ideals' (such as 'people' or 'nation') as 'ex post facto rationalisations' for actions of 'dubious characters' that need to be treated with suspicion. According to this view, such ideals can be dismissed in the analysis of political actors' behaviour as they 'play no causal role in bringing about their actions, and do not therefore need to figure in our explanations of their behaviour' ${ }^{38}$ As a consequence, any reference to these principles is dismissed. A similar vision of politics underpins much of the populism literature that claims that any reference to the people is purely strategic or stylistic. ${ }^{39}$ Skinner opposes this vision of politics. He argues that, even if principles rarely function as direct motives for political actors, they nevertheless make a difference in their behaviour, namely when a political agent acts in a way that is 'socially questionable' and possesses at the same time 'a strong motive for attempting ... to legitimize it' ${ }^{40}$ The 'rhetorical trick' in this process of legitimisation in a 'hostile' socio-lingual context consists of attributing a generally acceptable moral vocabulary to a "questionable social behaviour'.

With Skinner I conceptualise GNR intellectuals as ‘innovating ideologists’ whose defining task is to legitimise socially questionable behaviour. ${ }^{41}$ Their role is central as they develop, spread and employ a political language that links (populist) political practice to political theory and puts both into a mutually influencing relationship. In the case of the GNR, populist political practice is increasingly embedded in and legitimised by a political language elaborated by intellectuals. 
As the political vocabulary of a community, ${ }^{42}$ a political language is central to both the constitution and the legitimisation of social practice. A theoretical change in the vocabulary of a community will subsequently also change the social reality, the political institutions as well as the political practices. ${ }^{43}$ Political intellectuals can contribute to the altering and subverting of the dominant political language and 'communities of assumption $^{\text {,4 }}$ in such a way that the political reality they support appears as rational and legitimate. ${ }^{45}$ For the elaboration and spread of political language an exchange between intellectual 'elites' and 'the people' is central. Geiger defines intellectuals as 'creators of representative culture': artists, poets, writers, composers, scientists, inventors but also journalists and Volksredner (popular speakers). What is essential to qualify as an intellectual is not the degree of intellectual abstraction but the communicating intelligence and capacity to create new cultural values. Indispensable is the 'creation of culture' through 'a special system of development in a popular form' (my emphasis). ${ }^{46}$ Political language is not excluded from this process.

But what exactly is the 'questionable social behaviour' or political language GNR intellectuals aim to legitimise? What is central to the post-war far-right is 'nationalism' ${ }^{47}$ Nationalism is a 'thin-centred ideology' engaged in a power struggle over the 'selection, prioritization and combination of certain political concepts and the elimination of others' that, in order to become a full ideology, has to be complemented by other idea-systems such as the far-right ideology. ${ }^{48}$ Far-right nationalism 'presupposes that the nation-state is the necessary and natural form of society' ${ }^{49}$ In the far-right, populism is combined with nationalism in that the 'pure people' is conceived as the imagined community of the nation. ${ }^{50}$ However, this 'national people' is not necessarily opposed to any elite. Rather it 
is opposed to 'a current and illegitimate' elite that is seen as not representing the people or the nation. ${ }^{51}$ In the case of the German far-right, the questionable nationalism is not nationalism per se. ${ }^{52}$ Instead, the far-right's 'socially questionable' nationalism is an 'illicit nationalism ${ }^{, 53}$ reminiscent of Nazism through its exclusive ethnic understanding of nationhood. It is this exclusive priority of the nation ${ }^{54}$ that the GNR aims to legitimise in a context were nationalism is largely perceived as 'illicit'.

In what follows, the way Heidegger's philosophy is used as a resource in this process is analysed. Instead of falling into the established categories of ethnic and civic nationalism, ${ }^{55}$ the GNR puts forward an alternative Heidegger-inspired nationalism grounded in history and spirit ${ }^{56}$. It does not represent a sui generis nationalism but draws on narratives of German nationhood present in Heidegger's philosophy and early German anti-enlightenment nationalism, such as in $\operatorname{Herder}^{57}$ or Hegel. ${ }^{58}$ In this tradition, Heidegger's Dasein is used to reformulate an exclusive idea of nationhood in the context of a liberal democratic political language in which closeness to NS, racist nationalism and anti-Semitism are socially questionable and legally banned. ${ }^{59}$

\section{Heidegger's nation and Volk}

The following section focuses on Heidegger's notions of nation and Volk (people) before turning to GNR authors and the AfD. It will necessarily be a limited discussion restricted to sketching out those Heideggerian terms and concepts that lend themselves to a GNR use. $^{60}$

Heidegger's closeness to NS and his anti-Semitism ${ }^{61}$ have been subject to intense debates and have polarised scholarship into two rough camps: those who see Heidegger as the Nazi philosopher or his philosophy as contaminated by Nazism, ${ }^{62}$ and those who 
underline the value of Heidegger's philosophy independently of his Nazism. ${ }^{63}$ Regardless of this ongoing debate, the appeal of Heidegger's philosophy to the contemporary farright cannot be denied. Its far-right potential was explored only recently by Beiner, who has shown how the far-right appropriates Heideggerian philosophy as a sort of 'Heideggerian Neofascism' ${ }^{64}$ Heidegger's anti-liberalism and conviction that cultural decline and nihilistic modernity could be overcome by a fundamental rethinking of being under the 'guidance of German hyper-nationalism ${ }^{65}$ provides a useful intellectual resource for the GNR. His intellectual attraction towards a 'collective myth of sociocultural decline and renewal ${ }^{66}$ is equally at the core ${ }^{67}$ of the GNR and provides a common ground for actors from the far-right to conservatives.

Moreover, Heidegger's vision of intellectualism chimes with the GNR. He sees true intellectuals as 'closer to being' than 'ordinary intellectuals' ${ }^{68}$ These 'future ones', ${ }^{69}$ creators and deciders, include those statesmen, thinkers and artists with the spiritual access to the mystery of being he sees necessary to overcome modern nihilism. ${ }^{70} \mathrm{He}$ perceives them, and himself, at the same level as peasants and soldiers, both of which he equally believes to have a direct access to being. ${ }^{71}$ Here Heidegger's philosophy has a populist dimension, idealising the 'common folk' and fascinated with mass movements. ${ }^{72}$

Despite this affinity, Heidegger's philosophy plays only a minor role in the literature on far-right populism and/or the GNR, which mainly considers thinkers of the so-called 'Conservative Revolution' (CR) ${ }^{73}$ such as Spengler or Schmitt. ${ }^{74}$ While it is true that a large number of intellectuals have been influential on the GNR, Heidegger's role as a resource for contemporary NR thought remains under-researched. Analyses remain limited to GNR authors, ${ }^{75}$ activist and journalistic sources ${ }^{76}$ Central to this 
analysis is therefore the question of what role philosophy in general and Heidegger in particular plays in GNR nationalism and why? Exploring this may show how the GNR attempts to "override" 77 the social and legal constraints of the German post-war political system $^{78}$ and how far this ideological positioning can explain the current appeal of GNR thoughts.

\section{Dasein and Volk}

Dasein literally translates as 'being-there'. In Heidegger's seminal 1927 work Being and Time ${ }^{79}$ Dasein is the central concept of his philosophy of being. For Heidegger, the 'there' of Dasein constitutes a particular local form of universal human 'being' ${ }^{80}$ As human beings we are thrown into a specific 'there' at birth. This 'there' is defined first and foremost temporally ${ }^{81}$ and characterised by four dimensions: (1) our own beingtowards-death, the resulting (2) care about our individual lives, (3) the history into which we are born, and (4) our being-with-others.

The first two dimensions define our individual Dasein in a non-relational way. ${ }^{82}$ Individual birth and death, the two poles in between which Dasein unfolds, particularise universal human being. While we are in the world with others, we are with ourselves only in death. In the face of non-relational death, we become aware of our particular Dasein. This makes us care about the way in which we choose to be-towards-death, our life project. Through this caring, things matter to us. ${ }^{83}$ Dasein becomes authentic and manifest without retreating into the banal everyday life Heidegger associates with modern society. ${ }^{84}$ In this society, authentic Dasein has to be realised against the 'they' (Man), or, in other words, the mass of the people who 'do things' in an average way. Here, authentic Dasein is threatened by the 'other' of the 'they'. ${ }^{85}$ It is authentic in its 
being-towards-death as it faces us with nothingness, makes us step out of the average understanding of the 'they' and realise our singular existence. Through this existentialist dimension, Heidegger hopes to overcome Seinsvergessenheit, the forgetfulness of being he sees in modernity.

The other two dimensions through which human being is individuated and takes the shape of an authentic Dasein are history and being-with-others. ${ }^{86}$ Both are relational: ${ }^{87}$ being thrown into a particular historical 'there', we become part of a history and tradition that preceded us. Finally, individual Dasein is defined by its embeddedness in a being-with-others. It is here where Heidegger's concept of Dasein opens itself up for holistic interpretations. ${ }^{88}$ Dasein can only be understood in relation to the group one is part of. The 'there' of our Dasein is essentially a being-with-others, one's contemporaries. With them, the 'we' stands in a certain history that is understood as 'our' past, present and future. Besides space and time, it is these contemporaries who make the 'there' of Dasein specific. The historising of Dasein is for Heidegger a 'co-historizing'. ${ }^{89}$ Heidegger explicates a communitarian understanding of Dasein substantially only in the 1930s, but it is already visible in Being and Time:

If fateful Dasein, as Being-in-the-world, exists essentially in Being-with Others, its historizing is a co-historizing and is determinative for it as destiny. This is how we designate the historizing of the community of a people [Volksgemeinschaft] (...). Dasein's fateful destiny in and with its "generation" goes to make up the full authentic historizing of Dasein. ${ }^{90}$

In their relational dimension, history and being-with-others are necessary for authentic Dasein ${ }^{91}$ as 'Man as historical ... exists in the togetherness of a historical 
people' ${ }^{92}$ In Dasein, both individual and collective being are intertwined in multiplicity ${ }^{93}$ as authentic individual Dasein depends on its relation to the collective Dasein of a Volk. ${ }^{94}$

This thought forms the foundation for Heidegger's later fervent support of NS. ${ }^{95}$

As he argues in his 1933 Freiburg seminars, 'the destiny of a people has to be understood in distinctively historical terms.${ }^{96}$ Contrary to Nazism, he thus defines German nationhood not in racial terms ${ }^{97}$ but adheres to a 'spiritual racism' that defines national Dasein through its particular history. ${ }^{98}$

Heidegger further exposes his concept of the Volk in his 1934 lectures 'Logic as the Question Concerning the Essence of Language'. Defining for the Dasein of a Volk is the question of 'who are we ourselves?'. Asking this question, he argues, is timely as the question itself would be different from the central question of liberalism: 'who am I myself?' ${ }^{99}$ By asking the 'we-question' a 'we' is presupposed whose essence Heidegger sees defined by the Dasein as a Volk. The Dasein of a Volk is grounded in a history defined by the decision to be a Volk and manifested and formed politically in the figure of the state. ${ }^{100}$ By acting determinately together as a Volk, the 'we' draws on a common mandate derived from the past 'beenness' and tradition of the Volk. This tradition is handed down onto the 'we' in the present to 'labour' for a collective mission in the future. ${ }^{101}$ Here, the Volk, as a whole, cares about its being in the future. Through labouring as a Volk in the here and now, history is made, the Dasein of the Volk rerealised and manifested.

This man-made temporality of Volk and Dasein is a human phenomenon which goes, as Heidegger claims, beyond the modern distinction between subject and object, individual and society. The subject and the object have an ontic relationship in Dasein 
overlooked by the shallowness of modern thinking, ${ }^{102}$ where the external world is perceived as present-at-hand, as objectively alterable by mankind - a thinking Heidegger sees at the origin of technology and liberalism. ${ }^{103}$

While it is a matter of debate whether Being and Time is essentially political ${ }^{104}$ or apolitical, ${ }^{105}$ his 1930 s lectures explicitly reject modernity and liberalism. Both, he argues, undermine the essence of Dasein through the detachment from traditional bonds, community, dogmas and nature. ${ }^{106}$ For a 'genuine revolution of the whole of being' liberalism and its 'shallow' conception of being has to be fought. ${ }^{107}$ For Heidegger, there cannot be a society emerging out of a rational association of individuals but only a community of a Volk based on a historically handed-down determination to act together and to care about one's own existence. Through caring in the face of decline, the Volk continues to be a category of authentic Dasein and the defining principle of the selfhood of human being. ${ }^{108}$ Through its existentialism, Dasein is authentic and becomes an 'insurrection against nothingness', ${ }^{109}$ the same nothingness many CR thinkers saw in modern liberal society and that still builds the basis of unease with modernity present in the contemporary GNR.

\section{Universalism and Gestell}

Through his shift of focus to the collective level of Dasein $^{110}$ Heidegger moves the idea of the 'they' from the societal to the inter- or transnational level that takes the shape of a menacing 'uniform organization of reified humanity'. ${ }^{111}$ The 'other' is what threatens the Dasein of a Volk — universalism and a technological understanding of the world.

In the 1930s, Heidegger sees this threat in American capitalism and Russian/Asian communism both menacing Germany, the 'most metaphysical of 
nations'. ${ }^{112}$ For Heidegger, 'Russia and America are the same; the same dreary technological frenzy'. ${ }^{113}$ He sees in both the final political expression of the metaphysics of modernity carrying the telos of modern enlightenment in the shape of a universalism, a planetary state that subjugates the particular national Dasein. Heidegger's initial support for NS arose from the hope that it would awaken the spiritual force to protect the authentic Dasein of Germany and Europe against the homogenising imperial forces of America and Russia. ${ }^{114}$ At the end, Heidegger fears, stands a 'bloodless universalism'115 that perceives the world as a resource or 'standing-reserve', ${ }^{116}$ present-at-hand to be exploited and mastered by humanity, ${ }^{117}$ an end of national historicity and the death of authentic national Dasein. ${ }^{118}$ The world is understood as a resource to be exploited with modern technology, whose essence Heidegger calls Gestell. Through Gestell, the cultivation and revelation (aletheia) of the world happens through a purely technological and thus rational appreciation of the world that neglects traditional, spiritual forms ${ }^{119}$ and hollows out the authentic Dasein of the Volk. The result is a nihilistic Seinsvergessenheit, the forgetting of historical being of peoples, and a 'debased technocratic globalism'. ${ }^{120}$ In the face of this existential threat, Heidegger hopes the Volk will realise its being-towardsdeath, become aware of its non-relational difference and be carefully assertive about its future Dasein. ${ }^{121}$

Under Nazi rule this conviction makes Heidegger turn away from Nazism. For him, NS racism, technological fanaticism and striving for world domination came to represent the same modern Seinsvergessenheit that he saw at work in America and Russia. $^{122}$ The only answer, for Heidegger, is a return to authentic Dasein of a meaningful community of people able to decide its fate out of its historical being. 
In sum, central to Heidegger's philosophy is that both conceptually and semantically, it aims to establish a philosophy of being based on everyday life and terms, and as such it is still meaningful today. Conceptually, history is the core principle of Heidegger's collective national Dasein. Heidegger develops a form of spiritual nationalism that goes beyond a conventional chauvinistic nationalism driven by power and belief in supremacy, elevating the Volk to a metaphysical entity. ${ }^{123}$ By grounding a new beginning in the Dasein of the German people, he aims to set the first stone to overcome the nihilism of modernity ${ }^{124}$ and to protect the European peoples from the American and Asian/Russian threat by overcoming their 'own uprootedness' ${ }^{125}$

\section{Heidegger in New Right intellectualism}

The preceding section outlined how Heidegger defines Dasein at the individual and collective level as well as the anti-modernist and anti-liberal dimension in Heidegger's thought. The following section turns to the contemporary GNR and its appropriation of Heidegger. Not pretending to be an exhaustive review of the GNR use of Heidegger, it aims to provide examples of in-depth discussion of Heidegger, but also the use of Heideggerian 'sound bites' indicating a common political language and common understanding of Heidegger. I will focus first on the intellectual hubs of GNR thought in Schnellroda, Dresden and Berlin before turning to examples of Heideggerianism in the AfD.

\section{Schnellroda}

In the Staatspolitisches Handbuch on GNR 'Masterminds', published by the Schnellrodabased IfS, Heidegger is presented as having a 'direct ... influence on the intellectual 
Right' as his ideas are 'providing arguments in the metapolitical debate'. ${ }^{126}$ The IfS is not a think tank in the classical sense as it is not 'policy-producing' but rather 'cultureproducing', aimed at the German 'cultural Dasein' ${ }^{127}$ The idea of a particular German Dasein is also a regular subject of articles in the monthly IfS journal Sezession and other publications by the IfS or the GNR in general. Most authors and leading figures in the IfS have a background in philosophy, history or cultural studies, some with direct links to Heidegger or professors such as Ernst Nolte, who himself was a student of Heidegger. This also holds true for the authors of the Sezession's Heidegger issue. Published in February $2015^{128}$ when PEGIDA reached its climax, the spectrum of authors reaches from historian Ernst Nolte (internationally known for his work on fascism) $)^{129}$ to the leader of the Identitarian Movement, Martin Sellner. The journal mirrors the actual diversity of GNR intellectuals and reflects how the GNR's 'innovating ideologists' think about Heidegger and his philosophy. The different contributions focus on Heidegger and the way he is useful for 'the camp of the right', as Sellner puts it. ${ }^{130}$

In the introduction to the Sezession Heidegger issue, ${ }^{131}$ Kubitschek begins with a Heideggerian interpretation of LEGIDA (Leipzig variant of PEGIDA). Looking back at a speech he gave in front of protesters, ${ }^{132}$ he hopes that his words were able to put across the 'meaningful history of our people ... in whose heritage we stand'. Referring to history, he tried to 'include the whole Volk in our caring' (emphasis added). A common historical Dasein is presented as the common basis for a collective being, even with those who are assumed opponents of the GNR. In his eyes, the protesters symbolise the existence of the German Volk by expressing their 'care' about the German future. They 
represent a part of the Volk that 'still knows about itself', is aware of German Dasein and embodies it through its presence on the street.

Kubitschek frames the German Volk in the Heideggerian terms of history, care and Dasein - a conceptualisation inclusive only to all those who share German historical heritage. For Kubitschek, a 'meaningful [German] history' mobilises the people as the 'German Volk' who expresses its caring about its Dasein through protest in a time when the German Volk is 'first and foremost a form that is hollowed out, forced into the Gestell' ${ }^{133}$ With Heidegger, the Dasein of the people is defined in historical terms. The care about this Dasein expresses itself in the fear of a national death in the face of Gestell, globalisation and Islamisation. ${ }^{134}$ In Heidegger's terms: by caring about the possibility of the nation's non-relational death, the people becomes aware of itself as a collective agent in history.

Even if this short introduction represents anything but an in-depth analysis of Heidegger's philosophy, it shows how his vernacular notions are used by Kubitschek to make sense of and legitimise the protests on the street. The accuracy of the application of Heidegger to LEGIDA is of secondary importance, as the aim, the legitimisation of an exclusive nationalist movement and its alternative illicit political language through a great philosopher, is what is central here. Basing his nationalism on the morally acceptable, but through its dependence on historical legacy still exclusive principle of national history, Kubitschek attempts to legitimise illicit forms of nationalism. He argues that a belief in a common historical mission leads to the belief in a common fate necessary to resist transnational homogenisation and the meaningless Gestell. In the 
rational reading of being that he, and Heidegger, see at work in modernity, history has no place, as its meaningfulness is lost in a purely economic conception of the world. ${ }^{135}$

In another article in the same issue, Martin Sellner, philosophy student, leader of the Identitarian Movement, ${ }^{136}$ describes his 'path of thinking to Heidegger' ${ }^{137}$ He sees Heidegger as 'essential for a real understanding of our time and the mission of our camp', a 'spiritual King' whose concept of Dasein is the 'only, true and last enemy' of the 'project of the planetary human state', 'imperialistic rationality' and 'totalitarian enlightenment'. ${ }^{138}$ Heidegger is a mastermind because his revolutionary thinking was not only directed against the 'old bourgeois-metaphysical intellectualism' but also against the racist biologism and anti-Semitism of Nazism:

It [Heidegger's philosophy] questions all modes of nationalism ... and fascism as well as all conservative, religious or traditionalist ideas. ... The nationalist brotherhood wars, the biologic misconceptions of the ethnos, the fascist excess of statehood, the Führer cult, the megalomania, the ecstatic political religions ... and last but not least the enterprise ... to eliminate the alienation with modernity through the extermination of the biological Jew as modernity's 'demon'-all this appears ... as the expression of the forgetting and the oppression of the questions of being and truth which naturally leads to a 'loss of centre', and to a spiritual and political extremism. $^{139}$

As this quote shows, the seemingly post-racial and anti-NS aspect of Heideggerian philosophy is used to legitimise GNR nationalism against claims of racism or closeness to NS. It even opens itself up to leftist anti-capitalism as, according to Sellner, Heidegger's insistence on Dasein is the only way to resist a planetary capitalism destroying 'authentic Dasein'. Modern progress eradicates these 'different questionings 
and revelations of being' through its 'ever more progressive exploitation and exploration of being'. ${ }^{140}$

With Heidegger, Sellner summons the threat of a universal global state as a technocratic Gestell leading to the end of history and the particular historical Dasein of peoples. He celebrates the diversity of cultures only to use Heidegger to argue that this cultural diversity is under threat. As he states, 'Dasein is, in its questioning for its mode and being always rooted in a concrete ethnocultural soil ... a community and a world of language'. ${ }^{141}$ Sellner advocates asking 'the Heideggerian question of ... Dasein' that 'calls for a new fathoming of Heimat, Volk, Nation and Europe' and for the re-funding of nationalism in a seinsgeschichtlich (being-historical) way that deconstructs the Gestell of 'the postmodern "End of History", 142

The aim is to (re)legitimise the currently questionable idea of an exclusive nationalism by wrapping it in Heideggerian terminology of history and linking it to the GNR concept of ethnopluralism of a co-existence of ethno-culturally homogeneous but globally diverse peoples. ${ }^{143}$ As an innovating ideologist, Sellner uses the "prevailing vocabulary' of liberalism (such as 'diversity' or 'pluralism') ${ }^{144}$ to change the established political language from within. He shows 'that in spite of contrary appearances a number of favourable terms can be applied as apt descriptions of [one's] own apparently questionable behaviour'. ${ }^{145}$

One can object to such a reading as wrong or contradictory, especially because Heidegger would have refused any emphasis of ethnic properties. Moreover, Heidegger did not see all cultures as equal, but rather he saw Germany as the privileged expression of Dasein that was to save Europe from its spiritual decline. However, the essence both 
of ethnopluralism and Heidegger's philosophy forms the conviction that the particular Dasein is threatened by planetary Gestell. As Sellner argues in a different article for Sezession, Heidegger's thinking is a 'gatekeeper against the imperialistic reason and the totalitarian enlightenment' that threatens the 'authenticity' of things, humans, people and cultures. ${ }^{146}$

Another central GNR author is Martin Lichtmesz. He has been influential through contributions to Sezession but also through a number of books published with Antaios. Can Only a God Save Us? is one of these books. Its title refers directly to Heidegger's claim uttered in the famous 1966 Spiegel interview. ${ }^{147}$ Lichtmesz dedicated a whole chapter to Heidegger, ${ }^{148}$ focusing on his late philosophy and specifically his framing of modernity as culminating in an era where 'science and technology' have 'replaced God' and been given 'God-like status'. ${ }^{149}$ For Lichtmesz, this belief has become planetary, total and quasi-sacral, leading to 'disenchantment' and 'the vanishing of the mysterious, the mythical, the miraculous, the sacral, the numinous - all those irrational sources' that nurture life. ${ }^{150}$ These sources, however, are necessary in order to limit a 'moral of the feasible' and a belief that 'everything functions'. ${ }^{151}$ Appreciating human being through a purely technological appreciation of the world would make humanity live in a Gestell, the uprooting of human life based on a meaningless shaping of the planet through technology. More than that, the idea of the Gestell, Lichtmesz suggests, represents a domination of human Dasein through a technology that has developed its own force. This would eventually lead to catastrophes such as Auschwitz and the nuclear bomb as symbols for a planetary nihilism. According to Lichtmesz, 'all essential and great has 
only developed out of the fact that the human being had a Heimat and was rooted in tradition'. ${ }^{152}$

\section{Dresden}

More widespread than the in-depth-discussion of Heidegger's philosophy is the use of Heideggerian notions and 'sound bites' to read contemporary developments. For example, in a short piece in Tumult on the 2017 German elections, Lorenz Jäger, sociologist, journalist and former representative of the Frankfurt School, quotes Heidegger's alleged last handwritten words: 'What is needed is a reflection if and how in the era of a technological homogenous world civilisation a homeland can exist.' According to Jäger, the idea of such an era represents the 'madness that today enjoys highest recognition' by the mainstream. ${ }^{153}$ This reading of Heidegger points to a view of the world undermining Dasein similar to Lichtmesz and Sellner.

Another case for the application of Heideggerian thought to contemporary politics is a Tumult review ${ }^{154}$ of the exhibition 'The Invention of Human Races' in the Dresden Hygiene Museum. ${ }^{155}$ As the reviewer states, by suggesting that races are constructs, the exhibition postulates an ultimate universal truth and a horizontal homogenisation of humanity into equal races, ignoring the plurality of truth and the reality of difference between regions and countries. The exhibition implies that 'any form of thinking human Dasein like Heidegger ... as asserting and unfolding itself in a vertical way' through different kinds of being human is illicit. Like the IfS's use of Heidegger, the predominant idea of Dasein as universal human is seen to undermine the ethnopluralist diversity of human being. Pluralism as a positive term of the liberal democratic political language is 
here charged with an alternative meaning, applying it to a diversity of ethnicities and races that would be threatened by neoliberal globalisation and liberal universalism.

\section{Berlin}

Alongside the more activist IfS, the BdK has developed into a bourgeois platform bringing together widely accepted German politicians and political scientists, such as CDU member Wolfgang Bosbach ${ }^{156}$ and Werner Patzelt, ${ }^{157}$ AfD representatives and GNR intellectuals. In 2017, the Finnish literary scholar Tarmo Kunnas presented his book Fascination of an Illusion: European Intelligentsia and the Fascist Temptation 1919$1945^{158}$ on the main European figures of the CR. ${ }^{159}$ His presentation focused on Heidegger and the connection of his notion of politics and Dasein. According to Kunnas, Heidegger sees the Greek polis as the 'basis for being human': 'The idea of the polis is the "there" of Dasein', the 'historical site out of which Dasein is feeding itself'. This rootedness in a polis and 'direct access to being ... is the only way authenticity could be reached'. For Kunnas, Heidegger provides an important definition of politics not restricted to parties and the state but, as a 'great politics', including culture. He states that Heidegger was part of a whole range of conservative intellectuals who hoped that the convergence of the people, politics and 'artistic politics' would help to lead to a European renaissance and resistance to the 'decline of the European culture in materialism and plutocracy'. The nation as a part of great politics is here seen as a sort of spiritual platform bringing together elites and the people. Even if Kunnas presents the CR as a phenomenon of the past, the discussion following his presentation makes clear that his presentation is used as a tool to analyse the present. Most comments point to a perceived current decline of Europe and mention that looking back at the CR and Heidegger would 
be a useful way to face the 'contemporary cultural crisis'. How broad the range of farright politics is in the $\mathrm{BdK}$, as well as its international network, is shown by the fact that Kunnas has presented the same book to the fascist Casa Pound in Italy. ${ }^{160}$

Discussions of this sort are mainly limited to GNR intellectual circles but can be used more widely as a political language to legitimise or 'decontest' ${ }^{\text {' }}$ ' exclusive nationalism. ${ }^{162}$ The examples above show that intellectuals engage both intensively and sporadically with Heidegger's thought. They draw on his philosophy as one source to frame their worldview and define what a nation and a Volk is. For GNR innovating ideologists, Heideggerianism is attractive through its rejection of liberalism and its spiritual-historical understanding of the nation. But how much does Heidegger's thought play a role in the AfD?

\section{Heidegger, populism and the AfD}

As seen above, Heidegger's philosophy is one central resource arguing for a renewed German nationalism. GNR innovating ideologists draw on it to develop an alternative political language as a basis for a legitimate sense of national self-assertion. This political language can be used to frame and legitimise the political actions of leading members of the far-right populist AfD. Referring to Heidegger, who still is widely regarded as one of the greatest philosophers of the 20th century, may appeal to intellectual audiences who themselves are dissatisfied with contemporary politics. Elite support is a declared goal of the NR and seen as necessary and even more important than reaching mass support in order to bring about substantial social change through metapolitics. ${ }^{163}$

Referring to Heidegger can also impress a broader, more popular audience. This might be the intention of the articles on the far-right populist magazine Compact, where 
Heidegger's terms are used to justify calls for more national sovereignty to 'overcome the currently widespread idea of historylessness (Geschichtslosigkeit)' and rule of technology in the shape of a global 'digital totalitarianism'. ${ }^{164}$ In a Compact interview with French NR mastermind Alain de Benoist, Heidegger's terms are used to portray globalisation as a spread of 'individualism, the religion of human rights, the pre-eminence of selfinterests, the regression of all values for the profit of the market society and thus the permanent spread of the capitalist Gestell'. ${ }^{165}$

However, the focus of this last section will be on the use of this political language in the populist far-right AfD and figures linking the GNR, the AfD and social movements. Michael Klonovsky is a good example of the entanglement of GNR intellectualism and AfD populism. His popular blog Acta Diurna is a central reference in GNR circles. He was advisor to Frauke Petry, former leader of the AfD, and is the present assistant of Alexander Gauland, who has led the party together with Jörg Meuthen since 2017. On his blog, Klonovsky calls Heidegger's Being and Time 'one of my favorite books' before he quotes his favourite review of Being and Time by a reader on Amazon. Here Heidegger's work is seen as a masterpiece pushing the limits of human intelligence. ${ }^{166}$ In another blog post he quotes Heidegger disciple Ernst Nolte with the hope that 'our descendants don't fully dissolve in what ... Heidegger has called the Worldcivilisation ${ }^{167}$ Although this use of Heidegger's terms remains superficial, the explicit reference to him is nevertheless a means of legitimisation, a sign of cultivation. It equally shows that Heidegger's work has had an impact on central figures at the intersection of GNR intellectualism and AfD populism and that Heideggerianism is a common reference point of the GNR's alternative political language. 
But even at the AfD level, a deeper engagement with Heidegger can be observed. One of the most direct links between the GNR and the AfD leadership is Marc Jongen, former assistant to the German philosopher Peter Sloterdijk and now MP and AfD speaker in the state of Baden-Würtemberg. Jongen has himself presented a paper on 'Migration and Thymos-Training' in the IfS ${ }^{168}$ and was guest at the BdK. ${ }^{169}$ Initially seen as the AfD's party philosopher, his importance in the GNR and the AfD has been increasingly marginalised by the actors outlined above. Nevertheless, Jongen is another example of the import of Heideggerianism into the AfD's political language.

Jongen's philosophy is strongly influenced by Heidegger. His $\mathrm{PhD}$ is centred around the question of how to "reattribute exigent meaning to the notion of tradition, without falling behind the epochal lections of modernity? ${ }^{170}$ Following Heidegger and the CR, Jongen aims for a spiritual renewal in a meaningless present in order to overcome 'the modern phantasm of linear progress' ${ }^{171}$ Relying on Heidegger's notion of aletheia, he calls for an end to this time of 'oblivion of being' by uncovering the truth of history and thus a past meaningful for the present and future. ${ }^{172}$ Like Heidegger, he claims that the reason for this oblivion is modern metaphysics, and it can only be overcome through a post-metaphysical interpretation of being. He is convinced that with an oblivion of the truth of history, tradition and 'the origin ... there cannot be a future, or only a catastrophic future' ${ }^{173}$ To avoid such a catastrophe, a spiritual return to the origins is needed.

Jongen is an interesting case because as a philosopher and leading AfD member he is, as he says, active in two worlds: the academic-philosophical and the political. ${ }^{174}$ His interviews provide insight into how he translates his philosophical Heideggerianism 
into a political one. Here he calls for a spiritual renewal in the face of an Islamist threat through thymos - the emotional 'anger' necessary to overcome the logo-centric system of the established parties. While he concedes that summoning emotions and appealing to the spiritual in politics is a dangerous game, he says it's a risk worth taking 'if one wants to face the big existential menace of the perishing of the German culture'. ${ }^{175}$ To do so, a Heideggerian recovery of traditions would be necessary to invoke pride and anger against those who threaten them. He argues that even if they are social constructions, traditions are 'necessary illusions' to protect the 'cultural-religious superstructure' of the society. In this way, Germany would return to an authentic being based on a recognition and celebration of Germany's identity. Instead of being afraid of this, he says that 'the danger today is not so much that we will freeze our identity and commit to an aggressive nationalism, but rather that we lose what is proper to us'. ${ }^{176}$ Through his focus on the traditions and emotions of the Volk he oscillates between intellectualism and populism. By decontesting anger he clearly legitimates the anger visible in such populist movements as PEGIDA.

Last but not least, let us turn to one of the most prominent nationalist and populist politicians, Björn Höcke, AfD leader in Thuringia. Supported by national AfD leader Alexander Gauland, he is a close friend of Kubitschek, acts in close coordination with the IfS and regularly speaks at PEGIDA. ${ }^{177}$ An eloquent orator, Höcke puts the question of German nationhood at the centre of his speeches and calls for the (re)invention of traditions through the (re)discovering of 'authentic history'. Promoting the Kyffhäuser meeting organised as a 'new tradition' every year by the nationalist AfD section Der Flügel, Höcke implicitly refers to Heidegger: 'I think we founded a great tradition [the 
Kyffhäuser meeting] that is forward-looking. ... We ... as a Volk need a spiritual return to our great history, our great culture, to shape the future and to win back the future' ${ }^{178}$ At the AfD's 2015 national congress in Hanover, Höcke openly refers to Heidegger: 'As Germans we have to ask who we are. We need a "Yes" to the "Us".' The German people has to step out of its 'forgetfulness of being (Seinsvergessenheit)' and return to its 'order of being (Seinsordnung)'. 'Yes', he concludes, 'this is Heidegger'. ${ }^{179}$ This might represent a simplistic and distorted reading of Heidegger, ${ }^{180}$ but it nevertheless shows Heidegger's appeal to leading AfD politicians and the impact his words, even if used as 'sound bites', can have on a larger audience, specifically as part of an alternative political language.

Besides this more superficial use of Heidegger in speeches, Höcke talks in detail about his view on Heidegger in the recently published book Nie zweimal in denselben Fluss. The book represents an attempt to introduce Höcke, 'the populist', to a more intellectual leadership. In the introduction, Frank Böckelmann, core figure of the Dresden GNR and editor of Tumult, praises Höcke, specifically for his notion of the Volk: 'Here we hear not a culprit who is pilloried and is looking for excuses, but an intellectual, who has confidently thought through the notion of the "Volk" - a rarity in the political debate'. ${ }^{181}$

Höcke says that he 'stumbled upon' Heidegger's Being and Time as a young student ${ }^{182}$ and found his 'deeply felt anti-materialism confirmed. No viable ideas concerning order can be derived from materialistic ideologies, merely technocratic constructs... held together laboriously at the beginning of the 21 st century only through bread, games, manipulation and ... repression'. ${ }^{183}$ In the face of this 'national oblivion of being ... our 
Volk loses its soul' and a positive posture towards itself. ${ }^{184}$ Alluding to Heidegger's critique of the modern separation of subject and object and the conception of the world as Gestell, he calls for an understanding of Heimat not as 'some abstract environment standing in opposite to Man (dem Menschen gegenüber) but concretely the forests, meadows, fields, animals and plants of our homeland'. ${ }^{185}$ Höcke defines Volk as 'a unity of descent, language, culture and commonly experienced society. It is a human form of community ... not as close as a local tribe and not as distant as an abstract humanity'. ${ }^{186}$ This would lend it a complexity that 'universalist cosmopolitanism' cannot cope with.

With Heidegger, Höcke aims to subvert the established political language that associates populism with simplicity and complexity with realpolitik. He concedes that the notion of the Volk is a construction, but claims that this critique would be 'banal', as all human reality is a construction. Undermining the notion of the Volk, however, would be part of a dangerous trend in 'late modernity' in which it has become fashionable to 'to deconstruct what has developed and grown'. ${ }^{187}$ By not accepting this complexity and the spiritual depth of the being of the Volk, 'universalists' are the true racists as they deny the existence of people and propagate the utopia of a pure humanity 'empty of people (ohne völkisches)' ${ }^{188}$ In reality, the 'melting pot' argued for by liberals and multiculturalists would be a 'salad bowl' depriving the different peoples of their Dasein and destroying their diversity. ${ }^{189}$ Equally, his geopolitical analysis mirrors Heidegger's. Just as Heidegger sees the Dasein of the German Volk threatened by America and Russia, Höcke sees contemporary Europe in the pincers of neoliberal capitalism and Islam. ${ }^{190}$

The examples of Compact, Höcke, Klonovsky and Jongen demonstrate that the strong structural and ideological connection to the GNR allows AfD politicians to draw 
on a common political language elaborated by GNR intellectuals. The vocabulary

legitimises illicit forms of exclusive nationalism and nationalist political practice without employing an openly racist discourse. Furthermore, it shows that Heideggerian notions can be included in political speeches to mobilise support, be it among a more intellectual, well-educated electorate or a broader, more 'populist audience'.

\section{Conclusion}

This article has explored how GNR intellectuals draw on Heidegger's philosophy as 'innovating ideologists' to legitimise the 'questionable behaviour' of exclusive nationalism though the elaboration of an alternative political language. Central in this process is their embeddedness in a GNR civil society network that is a carrier and source of this language. Heidegger's philosophy is attractive to the GNR and the AfD for several reasons. First, Heidegger's vernacularism makes his terminology broadly applicable. Even if his philosophy is complex, the accessibility and meaningfulness of his core concepts makes them intelligible to intellectuals, politicians and broader audiences alike, even and especially when used as sound bites. Second, Heidegger's critique of NS reflects the GNR's self-understanding as a post-racist nationalism focused on the preservation of the historical Dasein of all peoples instead of a national world domination. Drawing on Heidegger's personal distancing from Nazism, NS is turned into the 'old right' — yet another expression of rationalist modernity destroying meaningful Dasein. Third, Heidegger's critique of modernity reflects a common narrative in German philosophical thought reaching back to such philosophers as Herder. Fourth, Heidegger's personal idealisation of 'the common folk' and his aim to bridge the gap between elites and Volk chimes with the GNR's aim to 'decontest' populism as well as the notion of the 
Volk. Finally, at a more general level, the central role of philosophy and such institutions as the IfS and the BdK reflects the importance of intellectuals in orienting, shaping and transforming the debates in the German public sphere in times of crisis ${ }^{191}$ in favour of the populist radical right.

Even if the GNR's use of Heidegger is a 'rhetorical trick' 192 to legitimise GNR nationalism, it would be short-sighted to portray this move as merely strategic. The examples presented here show that Heidegger is a recurring figure in GNR thought. GNR intellectuals engage with his philosophy and use it as a resource for their political language. His philosophy can be used to defend GNR ethnopluralism and, in embedding it into a liberal political language, modifies the established political language from within.

While it is true that through its vernacular terms, Heidegger's concepts are a convenient object for the projection of conservative to far-right ideology, the examples show that the GNR's worldview has much in common with Heidegger's ideas. Even when used as sound bites, Heideggerian terms have come to signify membership of a 'far-right club'. Drawing on Heidegger helps GNR nationalists to solidify their belief in what they see as their historical national mission. The reinterpretation of nationalism as a necessary fight against the 'forgetfulness of being' of technocratic capitalist globalisation provides the different actors of the GNR with a common raison d'être. It defies the conventional view of the far-right as a form of anti-intellectual populism whose reference to moral principles should be seen as a dubious practice, and allows the GNR to gain credibility among well-educated and even leftist audiences who see globalisation as a menace to local identities. Hence, focusing on the German far-right as a purely populist 
phenomenon neglects the role of GNR intellectualism and reflects a vision of politics where moral principles play no role. To follow such a vision risks ignoring the processes of legitimisation described above and thus underestimating the GNR's capacity to bring about social change.

Words: 9604

\section{Acknowledgements}

I would like to thank Simon Glendinning, Esra Ozyurek and Jonathan White for their extremely useful comments on earlier versions of this paper. Equally helpful was the rich feedback of the reviewers as well as the exchange with Ronald Beiner, who drew my attention to Heidegger's use of the term 'metapolitics'. 


\section{Notes}

${ }^{1}$ H. G. Betz, Radical Right-Wing Populism in Western Europe (Basingstoke: Macmillan, 1994);

P. Taggart, Populism (Buckingham: Open University Press, 2000); C. Mudde (Ed.), The Populist Radical Right: A Reader (London: Routledge, 2016); J. W. Müller, What Is Populism? (Philadelphia, PA: University of Pennsylvania Press, 2016); C. R. Kaltwasser, P. Taggart and P.O. Espejo (Eds), The Oxford Handbook of Populism (Oxford: Oxford University Press, 2017).

${ }^{2}$ See M. Berezin, Illiberal Politics in Neoliberal Times: Culture, Security and Populism in the New Europe (Cambridge: Cambridge University Press, 2009); F. Decker, Der neue Rechtspopulismus (Wiesbaden: VS Verlag für Sozialwissenschaften, 2004); S. M. Lipset, 'The radical right: A problem for American democracy', The British Journal of Sociology, 6/2 (1955), pp. 176-209; D. Halikiopoulou, 'What is new and what is nationalist about Europe's “new nationalism”?', LSE British Politics and Policy blog (2017), available at: http://blogs.lse.ac.uk/politicsandpolicy/what-is-new-and-what-is-nationalist-about-europesnew-nationalism/ (accessed 19 January 2017).

${ }^{3}$ E. Carter, 'Party ideology', in Mudde, Populist Radical Right, op. cit., Ref. 1, pp. 28-67; H. G. Betz and C. Johnson, 'Against the current-stemming the tide: The nostalgic ideology of the contemporary radical populist right', in Mudde, Populist Radical Right, op. cit., Ref. 1, pp. 68-82; M. Freeden, 'After the Brexit referendum: Revisiting populism as an ideology', Journal of Political Ideologies, 22/1 (2017), pp. 1-11; M. Kenny, 'Back to the populist future? Understanding nostalgia in contemporary ideological discourse', Journal of Political Ideologies, 22/3 (2017), pp. 256-273.

${ }^{4}$ B. Stanley, 'The thin ideology of populism', Journal of Political Ideologies, 13/1 (2008), pp. 95-110.

${ }^{5}$ C. Mudde, 'Populism. An ideational approach', in Kaltwasser et al. (Eds), op. cit., Ref. 1, pp. 29-30.

${ }^{6}$ See N. Berbuir, M. Lewandowsky and J. Siri, 'The AfD and its sympathisers: Finally a rightwing populist movement in Germany?', German Politics, 24/2 (2014), pp. 1-25; K. Arzheimer, 'The AfD: Finally a successful right-wing populist Eurosceptic party for Germany?', West European Politics, 16/2 (2015), pp. 1-22; P. Taggart, 'Populism in Western Europe', in Kaltwasser et al. (Eds), op. cit., Ref. 1, pp. 248-263. 
${ }^{7}$ As part of my fieldwork I spent nine months (November 2017-July 2018) in Germany, participating in numerous GNR events, book readings and presentations in Dresden and Berlin.

${ }^{8}$ Q. Skinner, Visions of Politics (Cambridge: Cambridge University Press, 2002), p. 148.

${ }^{9}$ Brubaker defines exclusive nationalism as based on an 'ethnonational fact' rather than on a 'political claim' as in inclusive civic forms of nationalism, see R. Brubaker, 'In the name of the nation: Reflections on nationalism and patriotism 1', Citizenship Studies, 8/2 (2004), pp. $115-127$.

${ }^{10}$ The GNR also draws on other Heideggerian notions such as Gelassenheit (releasement or serenity) as a mode of resistance. For this see M. Sellner and W. Spatz, Gelassen in den Widerstand. Ein Gespräch über Heidegger (Schnellroda: Kaplaken, 2015). However, for the sake of my argument I will focus on Heideggerian notions that lend themselves to a legitimisation of nationalism rather than modes of political activism.

${ }^{11}$ PEGIDA (Patriotic Europeans against the Islamisation of the Occident) is a social movement founded in Dresden, Saxony. In early 2015 the movement reached 20,000 participants and spread to other German cities. See W. J. Patzelt and J. Klose, PEGIDA: Warnsignale aus Dresden (Dresden: Thelem, 2016), p. 31.

12 W. Gessenharter, 'Intellektuelle Strömungen und Vordenker in der deutschen Neuen Radikalen Rechten', in T. Grumke and B. Wagner (Eds), Handbuch deutscher Rechtsradikalismus (Opladen: Leske \& Budrich, 2002), pp. 189-201; V. Weiß, Die autoritäre Revolte: die Neue Rechte und der Untergang des Abendlandes (Stuttgart: KlettCotta, 2017).

${ }^{13}$ W. Gessenharter, 'Die "Neue Rechte" als Scharnier zwischen Neokonservatismus und Rechtsextremismus in der Bundesrepublik', in R. Eisfeld and I. Müller (Eds), Gegen Barberei: Essays Robert M. W. Kempner zu Ehren (Frankfurt am Main: Athenäum, 1989), pp. 424-452; W. Gessenharter, 'Neue radikale Rechte: Intellektuelle neue Rechte und Rechtsextremismus: zur theoretischen und empirischen Neuvermessung eines politischideologischen Raumes, in W. Gessenharter and H. Fröchling (Eds), Rechtsextremismus und Neue Rechte in Deutschland. Neuvermessung eines politisch-ideologischen Raumes? (Opladen: Leske \& Budrich, 1998), pp. 25-66; Gessenharter, 'Intellektuelle Strömungen', op. cit., Ref. 11; W. Gessenharter, Die Neue Rechte - eine Gefahr für die Demokratie? (Wiesbaden: Springer, 2004); A. Pfahl-Traughber, Konservative Revolution und Neue Rechte: Rechtsextremistische Intellektuelle gegen den demokratischen Verfassungsstaat (Opladen: Leske \& Budrich, 1998); R. Stöss, Die 'neue Rechte' in der Bundesrepublik 
(Bundeszentrale für Politische Bildung, 2007), available at http://www.bpb.de/politik/extremismus/rechtsextremismus/41435/die-neue-rechte-in-derbundesrepublik? $\mathrm{p}=0$ (accessed 2 November 2017).

${ }^{14}$ S. Salzborn, 'Renaissance of the New Right in Germany: A discussion of New Right elements in German right-wing extremism today', German Politics and Society, 34/2 (2016), pp. 4345.

${ }^{15}$ J. W. Müller, Another Country. German Intellectuals, Unification and National Identity (New Haven: Yale University Press, 2000), specifically chapter 7, here pp. 222-225.

${ }^{16}$ Gessenharter, 'Die "Neue Rechte” als Scharnier', op. cit., Ref. 12.

${ }^{17} \mathrm{~K}$. Goschler, 'Radical conservative thought in the intellectual constellation of the early Federal Republic,' Cultural Critique, 69 (2008), p. 3; A. Schildt, Konservatismus in Deutschland: von den Anfängen im 18. Jahrhundert bis zur Gegenwart (Munich: Beck, 1998), p. 20. Müller argues that this 'traditional German chasm between Geist [intellect] and Macht [power]' was in fact overcome after the Second World War (Müller, Another Germany, op. cit., Ref. 14, p. 8).

${ }^{18}$ V. Molnár, 'Civil society, radicalism and the rediscovery of mythic nationalism', Nations and Nationalism, 22/1 (2016), pp. 165-185.

${ }^{19}$ J. Göpffarth 'The rise of Germany's AfD: From ordoliberalism to nationalism and into the Bundestag?', Democratic Audit UK blog, available at: http://www.democraticaudit.com/2017/06/29/the-rise-of-germanys-afd-fromordoliberalism-to-nationalism-and-into-the-bundestag/ (accessed 1 July 2018).

${ }^{20}$ The Christian Democratic Union is the party of current Chancellor Angela Merkel. Lengsfeld gained prominence as a citizen's rights activist in the socialist GDR and, until the 2015 refugee crisis, was a strong supporter of Merkel.

${ }^{21}$ For a detailed visualisation of the GNR networks, see C. Fuchs and P. Middelhoff, 'Bis in den letzten, rechten Winkel', Zeit Online, 12 May 2018, available at: https://www.zeit.de/politik/deutschland/2018-05/neue-rechte-verteilung-deutschlandkarte (accessed on 4 July 2018).

${ }^{22}$ See, for example, R. P. Sieferle, Finis Germania Kaplaken 5 (Schnellroda: Antaios, 2017); M. Lichtmesz and M. Ley, Nationalmasochismus (Schnellroda: Antaios, 2018).

${ }^{23}$ See, for example, T. Sarrazin, Deutschland schafft sich ab: wie wir unser Land aufs Spiel setzen 4 (Munich: Deutsche Verlags-Anstalt, 2010); T. Sarrazin, Feindliche Übernahme: Wie der Islam den Fortschritt behindert und die Gesellschaft bedroht (Munich: Finanzbuchverlag, 2018). 
${ }^{24}$ See, for example, G. Scholdt, Literarische Musterung: Warum wir Kohlhaas, Don Quijote und 
andere Klassiker neu lesen müssen (Schnellroda: Antaios, 2017).

${ }^{25}$ See, for example, L. Fritze, Der böse gute Wille: Weltrettung und Selbstaufgabe in der Migrationskrise (Berlin: Manuscriptum, 2016).

${ }^{26}$ See, for example, B. Rosenkranz, Wie das Projekt EU Europa zerstört: Eine überzeugte Europäerin rechnet ab. (Graz: Ares, 2014).

${ }^{27}$ R. Kaplan, 'France's New Right', Commentary, 69/3 (1980), p. 49; P. A. Taguieff, 'Origines et métamorphoses de la Nouvelle Droite', Vingtième Siècle. Revue d'histoire 40 (1993), pp. 322; J. W. Müller, 'From national identity to national interest: The rise (and fall) of Germany's new right', German Politics 8/3 (1999), pp. 1-20; A. Cole, 'Old right or new right? The ideological positioning of parties of the far right', European Journal of Political Research, 44/2 (2005), pp. 203-230; M. C. Casadio, 'The new right and Metapolitics in France and Italy', Journal for the Study of Radicalism, 8/1 (2014), pp. 45-86.

${ }^{28}$ Salzborn, op. cit., Ref. 13.

${ }^{29}$ K. Biermann, A. Geisler, C. Holzinger, P. Middelhoff , K. Polke-Majewski and T. Steffen, 'Rechts bis extrem im Bundestag', Zeit Online (2017). Available at: http://www.zeit.de/politik/deutschland/2017-09/afd-kandidaten-bundestagswahlabgeordnete.

${ }^{30}$ Göpffarth, 'The rise of Germany's AfD', op. cit., Ref. 17; J. Bender and R. Bingener, 'Das wird man wohl noch aushalten dürfen', Frankfurter Allgemeine Zeitung Online (2015), available at: http://www.faz.net/aktuell/politik/inland/die-afd-feiert-ihre-einheit-auf-dembundesparteitag-13939205.html (accessed 11 December 2017).

${ }^{31}$ I attended Lehnert's presentation entitled 'Mobilmachung - Waldgang - Weltstaat. Ernst Jünger's political philosophy', given in the AfD's Bundestag offices on 6 June 2018.

${ }^{32}$ M. Kamann and A. Naumann, 'AfD lädt völkischen Strategen in den Bundestag ein', Welt (2018), https://www.welt.de/politik/deutschland/article178697524/AfD-laedt-voelkischenStrategen-in-den-Bundestag-ein.html (accessed 5 July 2018).

${ }^{33}$ Declaration 2018; see Erklärung 2018, https://www.erklaerung2018.de/ (accessed 15 June 2018).

${ }^{34}$ AfD, 'Aktuelle Beschlusslage des AfD-Bundesverbandes zu PEGIDA (Dresden)', AfD Kompakt (5 May 2018), https://afdkompakt.de/2018/03/05/beschlusslage-auf-der-ebenedes-afd-bundesverbandes-zu-pegida-dresden/ (accessed 2 July 2018).

${ }^{35}$ S. Weiland, 'Steuergeld für die AfD-Kulturrevolution', Spiegel Online (2 July 2018), http://www.spiegel.de/politik/deutschland/afd-desiderius-erasmus-stiftung-soll-partei-ingesellschaft-verankern-a-1216022.html (accessed 8 July 2018). 
${ }^{36}$ R. Vehrkamp and K.Wegschaider, 'Populäre Wahlen. Mobilisierung und Gegenmobilisierung der sozialen Milieus bei der Bundestagswahl 2017', Bertelsmann Stiffung (2017), https://www.bertelsmann-stiftung.de/de/publikationen/publikation/did/populaere-wahlen (accessed on 23 September 2017); H. Lengfeld, 'Die “Alternative für Deutschland”: eine Partei für Modernisierungsverlierer?', KZfSS Kölner Zeitschrift für Soziologie und Sozialpsychologie, 69/2 (2017), pp. 209-232.

${ }^{37}$ F. Finkbeiner, J. Schenke, K. Trittel, C. Schmitz and S. Marg, 'PEGIDA: Aktuelle Forschungsergebnisse', Göttingen: Institut für Demokratieforschung (2016), http://www.demokratie-goettingen.de/blog/pegida-2016-studie (accessed 27 June 2018).

${ }^{38}$ Skinner, Visions, op. cit., Ref. 8, p. 145.

39 cf. B. Moffitt, The Global Rise of Populism: performance, Political Style, and Representation (Stanford, CA: Stanford University Press, 2017); K. Weyland, 'Populism: A politicalstrategic approach, in Kaltwasser et al. (Eds), op. cit., Ref. 1, pp. 48-72.

${ }^{40}$ Skinner, Visions, op. cit., Ref. 8, p. 146.

${ }^{41}$ Skinner, , p. 148.

${ }^{42}$ H. Rosa 'Ideengeschichte und Gesellschaftstheorie: Der Beitrag der "Cambridge School” zur Metatheorie', Politische Vierteljahresschrift, 35/2 (1994), pp. 197-223.

${ }^{43}$ J. Pocock, 'The history of political thought: A methodological enquiry', in P. Laslett and W. G. Runciman (Eds), Philosophy, Politics and Society (Second Series) (Oxford: Basil Blackwell, 1962), pp. 183-202; J. Pocock, Politics, Language and Time. Essays on Political Thought and History (Chicago, IL: University of Chicago Press, 1971); Q. Skinner, 'Language and social change', in J. Tully (Ed.), Meaning and Context: Quentin Skinner and His Critics (Princeton, NJ: Princeton University Press, 1989), pp. 119-132; C. Taylor, 'Interpretation and the sciences of man', The Review of Metaphysics, 25/1 (1971), pp. 3-51.

${ }^{44}$ A. Etzioni, 'Are public intellectuals an endangered species?', in A. Etzioni and A. Bowditch (Eds) Public Intellectuals: An Endangered Species? (New York: Rowman \& Littlefield, 2006), pp. 1-27.

${ }^{45}$ Rosa, op. cit., Ref. 40, p. 213.

${ }^{46}$ T. Geiger, Aufgaben und Stellung der Intelligenz in der Gesellschaft (Stuttgart: Enke, 1949), pp. 13-17.

${ }^{47}$ C. Mudde, Populist Radical Right Parties in Europe (Cambridge: Cambridge University Press, 2007), pp. 18-24.

${ }^{48}$ M. Freeden, 'Is nationalism a distinct ideology?', Political Studies, XLVI (1998), pp. 751-752. 
${ }^{49}$ C. Mudde, 'The populist radical right: A pathological normalcy', West European Politics, 33/6 (2010), p. 1173.

${ }^{50}$ C. Mudde, 'Populism. An ideational approach', in Kaltwasser et al. (Eds), op. cit., Ref. 1, pp. $31-32$.

${ }^{51}$ B. De Cleen, 'Populism and nationalism', in Kaltwasser et al. (Eds), op. cit. Ref. 1, p. 345.

${ }^{52}$ For a discussion of the banality of nationalism, see U. Özkirimli, Theories of Nationalism: A Critical Introduction (Basingstoke: Palgrave Macmillan, 2010); M. Canovan, Nationhood and Political Theory (Cheltenham: Edward Elgar, 1996) and M. Billig, Banal Nationalism (London: Sage, 1995).

${ }^{53}$ N. Shoshan, The Management of Hate: Nation, Affect, and the Governance of Right-Wing Extremism in Germany (Princeton, NJ: Princeton University Press, 2016), p. 176.

${ }^{54}$ Freeden, 'Is nationalism a distinct ideology?', op. cit., Ref. 46, p. 750.

${ }^{55}$ H. Kohn, The Idea of Nationalism: A Study in Its Origins and Background (London: Routledge 2005). For a critical assessment of the civic-ethnic dichotomy, see A. Lecours, 'Ethnic and civic nationalism: Towards a new dimension', Space and Polity, 4/2 (2000), pp. 153-166; T. Kuzio, 'The myth of the civic state: A critical survey of Hans Kohn's framework for understanding nationalism', Ethnic and Racial Studies, 25/1 (2002), pp. 20-39 and D. Halikiopoulou, S. Mock and S. Vasilopoulou, 'The civic zeitgeist: Nationalism and liberal values in the European radical right', Nations and Nationalism, 19/1 (2013), pp. 107-127.

${ }^{56}$ This is in no way a new strategy but an updated version of the GNR's 'Detour via history' (see Müller, Another Country, op. cit., Ref. 14, pp. 207-210.

${ }^{57}$ J. G. Herder, Ideen zur Philosophie der Geschichte der Menschheit (Leipzig: Hartknoch, 1787).

${ }^{58}$ J. Phillips, Heidegger's Volk: between National Socialism and poetry (Stanford, CA: Stanford University Press, 2006), p. 32; J. Göpffarth, 'French and German nationalism. A common history from the French Revolution to the New Right', Countering Populism and Political Disaffection (8 May 2017): http://countering-populism.eu/french-and-german-nationalisma-common-history-from-the-french-revolution-to-the-new-right/.

${ }^{59}$ Gessenharter, 'Die “Neue Rechte” als Scharnier', op. cit., Ref. 12; Gessenharter, 'Intellektuelle Strömungen', op. cit., Ref. 11.

${ }^{60}$ Heidegger is not only a central influence in the GNR. In Russia, Alexander Dugin uses Heidegger's philosophy to develop a 'fourth political theory' overcoming Marxism, Fascism and Capitalism; see A. Dugin, The Fourth Political Theory (London: Arktos, 2012) and A. Dugin and P. E. Gottfried, Martin Heidegger: The Philosophy of Another Beginning 
(Whitefish: Washington Summit Publishers, 2014). Equally, in France, Heidegger has been important for the Nouvelle Droite (see Taguieff, op. cit., Ref. 25). O'Meara argues that Heidegger is the central philosopher for the international NR (see M. O'Meara, New Culture, New Right: Anti-Liberalism in Postmodern Europe (London: Arktos, 2004), p. 156;

R. Beiner, Dangerous Minds. Nietzsche, Heidegger, and the Return of the Far Right (Philadelphia, PA: Penn Press, 2018), pp. 67-69).

${ }^{61}$ cf. P. Trawny, Gesamtausgabe. 94: 4. Abt., Hinweise und Aufzeichnungen, Überlegungen (Frankfurt am Main: Klostermann, 2014).

${ }^{62}$ For example, E. Faye, A. Watson and R. J. Golsan, 'Nazi foundations in Heidegger's work', South Central Review, 23/1 (2006), pp. 55-66; E. Faye, Heidegger: The Introduction of Nazism into Philosophy, trans. Michael B. Smith (New Haven: Yale University Pres , 2009); C. Bambach, Heidegger's Roots: Nietzsche, National Socialism, and the Greeks (Ithaca, NY: Cornell University Press, 2003); A. Karademir, 'Heidegger and Nazism: On the relation between German conservatism, Heidegger, and the National Socialist Ideology', Philosophical Forum, 44/2 (2013), pp. 99-123; P. Trawny, Heidegger und der Mythos der jüdischen Weltverschwörung, 1. Aufl (Frankfurt am Main: Klostermann, 2014); I. Farin and J. Malpas (Eds), Reading Heidegger's Black Notebooks - 1931-1941 (London: The MIT Press, 2016).

${ }^{63}$ For example, F. Dallmayr , The Other Heidegger (Ithaca: Cornell University Press, 1993); M. O'Brien, Heidegger, History and the Holocaust (London: Bloomsbury Academic, 2015).

${ }^{64}$ Beiner, Dangerous Minds, op. cit., Ref. 57, p. 67, footnote 5.

${ }^{65}$ Beiner, ibid., p. 72.

${ }^{66}$ M. Feldmann, 'Between Geist and Zeitgeist: Martin Heidegger as ideologue of 'Metapolitical Fascism', Totalitarian Movements and Political Religions, 6/2, (2011), p. 176.

${ }^{67}$ The term core is here used in Freeden's sense, M. Freeden. 'Political concepts and ideological morphology', Journal of Contemporary History, $2 / 2$ (1994), pp.140-164. Nationalism provides the core of the GNR's political language while the different actors represent a variety of adjacent views and currents, ranging from fascism to conservatism, ordoliberalism to the socialist 'Querfront', B. Kaiser, Querfront: Kaplaken Band 49 (Schnellroda: Antaios, 2017).

${ }^{68}$ Beiner, Dangerous Minds, op. cit., Ref. 57, p. 104.

${ }^{69}$ M. Heidegger, Contributions to Philosophy (of the Event) (Bloomington: Indiana University Press, 2012), p. 76. 
${ }^{70}$ G. Bennington, Scatter 1. The Politics of Politics in Foucault, Heidegger, and Derrida (New York: Fordham University Press, 2016), pp. 213-222.

${ }^{71}$ Beiner, Dangerous Minds, op. cit., Ref. 57, p. 104.

${ }^{72}$ Beiner, ibid., p. 74, footnote 19.

${ }^{73}$ A term coined by one of the leading figures of the German post-war NR Armin Mohler in his PhD thesis: A. Mohler, Die konservative Revolution in Deutschland 1918-1932: Grundriß ihrer Weltanschauungen (Stuttgart: Vorwerk, 1950), later published as the book The Conservative Revolution in Germany: 1918-1932 (Graz: Arles, 2005). Mohler describes the $\mathrm{CR}$ as a nationalist movement, whose primary aim is not to establish a nation state but rather 'state of soul', the feeling of Germanness. Despite its GNR origin, the term 'CR' is today widely accepted in academia (for a discussion of the CR see M. Travers, Critics of Modernity: The Literature of the Conservative Revolution in Germany, 1890-1933 (New York: Peter Lang, 2001); R. Woods, The Conservative Revolution of the Weimar Republic (Basingstoke: Palgrave Macmillan, 1996); U. Puschner (Ed.), Handbuch zur "Völkischen Bewegung”: 1871-1918 (Munich: Saur, 1996).

${ }^{74}$ See D. Prowe, 'Fascism and the New Radical Right in Western Europe: Comparisons and contrasts', Contemporary European History, 3/3 (1994), pp. 289-313; Pfahl-Traughber, op. cit., Ref. 12; R. Woods, Germany's New Right as Culture and Politics (Basingstoke: Palgrave Macmillan, 2007); K. Abts and S. Rummens, 'Populism versus democracy', Political Studies, 55/2 (2007). pp. 405-424; Müller, What Is Populism?, op. cit. Ref. 1, p. 28.

${ }^{75}$ M. O’Meara, op. cit., Ref. 57.

${ }^{76}$ P. Zorn, 'Höcke und Heidegger', Hohe Luft (3 December 2015): https://www.hoheluftmagazin.de/2015/12/hoecke-und-heidegger/ (accessed 4 July 2018); M. Brumlik, 'Das alte Denken der neuen Rechten: Mit Heidegger und Evola gegen die offene Gesellschaft', Blätter für deutsche und internationale Politik, 3 (2016), pp. 81-92; Weiß, op. cit., Ref. 11.

${ }^{77}$ Skinner, Visions, op. cit., Ref. 8, p 149.

${ }^{78}$ The banning of the Socialist Imperial Party (1952) and the German Communist Party (1956) led to the institutional definition of basic values and the legal foundation for the 'liberal democratic order' of the Federal Republic in Germany. These values include the respect of human rights, pluralism of political parties and parliamentary opposition. The respect of these values, and not the ideological closeness to NS, forms a legal basis for deciding if a party is extremist and may be legally prosecuted; see Gessenharter and Fröchling, op.cit., Ref. 12, p. 109. 
${ }^{79}$ M. Heidegger, Being and Time (Oxford: Blackwell, 2001).

${ }^{80}$ Beiner, Dangerous Minds, op. cit., Ref. 57, p. 75.

${ }^{81}$ Heidegger, Being and Time, op. cit., Ref. 76, p. 277.

${ }^{82}$ Heidegger, ibid., p. 308.

${ }^{83}$ Beiner, Dangerous Minds, op. cit., Ref. 57, p. 80.

${ }^{84}$ R. Polt, Heidegger: An Introduction (Ithaca, NY: Cornell University Press, 1999), pp. 23-80.

${ }^{85}$ Heidegger, Being and Time, op. cit., Ref. 76, p. 296-298.

${ }^{86}$ Polt, op. cit., Ref. 81, pp. 5-6.

${ }^{87}$ Phillips, op. cit., Ref. 55, p. 14.

${ }^{88}$ Bambach, op. cit., Ref. 59, pp. 99-107; M. Heinz, 'Investigations of Heidegger's seminar, “On the Essence and Concept of Nature, History, and State", in M. Heidegger, Nature, History, State: 1933-34 (London: Bloomsbury, 2013). pp. 72-73.

${ }^{89}$ Phillips, op. cit., Ref. 55, p. 13.

${ }^{90}$ M. Heidegger, Being and Time, transl. by John Macquarrie and Edward Robinson (Oxford: Blackwell, 1962), p. 436. For this quote I chose to use a different Being and Time edition as the translation better conveys the original German text.

${ }^{91}$ P. Osborne, The Politics of Time: Modernity and Avant-Garde (London: Verso, 2011), p. xii.

${ }^{92}$ M. Heidegger, Being and Truth (Bloomington: Indiana University Press, 2010), p. 200.

${ }^{93}$ Phillips, op. cit., Ref. 55, p. 13.

${ }^{94}$ U. Steinvorth, Pride and Authenticity (Basingstoke: Palgrave Macmillan, 2016), p. 91.

${ }^{95}$ Phillips, op. cit., Ref. 55, p. 13.

${ }^{96}$ M. Heidegger, Nature, History, State: 1933-1934, G. Fried (Ed.) (London: Bloomsbury Academic, 2013), p. 5.

${ }^{97}$ Phillips, op. cit., Ref. 55, p. 15.

${ }^{98}$ O’Brien, op. cit., Ref. 60, pp. 88-89; J. Derrida, De l'esprit: Heidegger et la question (Paris: Éditions Galilée, 1987).

${ }^{99}$ M. Heidegger, Logic as the Question Concerning the Essence of Language (Albany: State University of New York Press, 2009), p. 45.

${ }^{100}$ Heinz, op. cit., Ref. 85, p. 76.

${ }^{101}$ Heidegger, Logic as the Question, op. cit., Ref. 96, pp. 109, 129-131.

102 Beiner, Dangerous Minds, op. cit., Ref. 57, p. 87.

${ }^{103}$ Heidegger, Logic as the Question, op. cit., Ref. 96, p. 121; Heidegger, Nature, History State, op. cit., Ref. 93, p. 52.

${ }^{104}$ Phillips, op. cit., Ref. 55, p. 13. 
${ }^{105}$ D. Janicaud, The Shadow of That Thought, trans. Michael Gendre (Evanston, IL: Northwestern University Press, 1996), pp. 37-41.

${ }^{106}$ Heidegger, Logic as the Question, op. cit., Ref. 96, p. 121.

${ }^{107}$ Heidegger, ibid., p. 126.

${ }^{108}$ Heidegger, ibid., p. 139.

${ }^{109}$ Heidegger, quoted in Beiner, Dangerous Minds, op. cit., Ref. 57, p. 76.

${ }^{110}$ Bennington, op. cit., Ref. 67, p. 220; Feldmann, op. cit., Ref. 63, p. 182.

${ }^{111}$ Phillips, op. cit., Ref. 55, p. 32.

112 M. Heidegger, An Introduction to Metaphysics (New York: Anchor Books, 1961), pp. 31-32.

${ }^{113}$ Heidegger, ibid., pp. 37-38.

${ }^{114}$ T. Kisiel, 'Heidegger's philosophical geopolitics in the Third Reich', in R. Polt and G. Fried, A Companion to Heidegger's Introduction to Metaphysics (London: Yale University Press, 2001), p. 228; D. Di Cesare, 'Die Heimat der Verschiedenheit: Über die plurale Identität Europas', in W. Stegmaier (Ed.) Europa-Philosophie (Berlin: Walter de Gruyter, 2000), pp. 116; Phillips, op. cit., Ref. 55, p. 32.

${ }^{115}$ O’Brien, op. cit., Ref. 60, pp. 78-79.

${ }^{116}$ M. Heidegger, The Question Concerning Technology, and Other Essays. W. Lovitt (Ed.) (New York: Harper \& Row, 1977), p. 8.

${ }^{117}$ Heidegger, ibid.

${ }^{118}$ O’Brien, op. cit., Ref. 60, p. 70.

${ }^{119}$ M. Heidegger, Die Technik und die Kehre (Pfullingen: Neske, 1962), p. 20; Heidegger, Question Concerning Technology, op. cit., Ref. 113, p. 9; O'Brien, op. cit., Ref. 60, p. 24.

${ }^{120}$ O'Brien, op. cit., Ref. 60, p. 70.

${ }^{121}$ Phillips, op. cit., Ref. 55, p. 3.

${ }^{122}$ Osborne, op. cit., Ref. 88, p. 163.

${ }^{123}$ Beiner, Dangerous Minds, op. cit., Ref. 57, p. 96.

${ }^{124}$ Beiner, ibid., p. 98.

${ }^{125}$ M. Heidegger, 'Europe and German philosophy', The New Yearbook for Phenomenology and Phenomenological Philosophy VI (2006), p. 331.

${ }^{126}$ E. Lehnert and K. Weißmann, Staatspolitisches Handbuch. Band 3. Vordenker (Schnellroda: Antaios, 2012), p. 7.

${ }^{127}$ E. Kositza and G. Kubitschek, Tristesse Droite. Die Abende von Schnellroda (Schnellroda: Antaios, 2015).

${ }^{128}$ Institut für Staatspolitik (IfS), 'Heidegger', Sezession, 13/64 (2015). 
${ }^{129}$ E. Nolte, Three Faces of Fascism: Action Française, Italian Fascism, National Socialism (New York: Mentor, 1969).

${ }^{130}$ M. Sellner, 'Wer sich distanziert, verliert?', Indentitäre Bewegung, https://www.identitaerebewegung.de/blog/wer-sich-distanziert-verliert/ (accessed on 2 July 2018).

${ }^{131}$ IfS, op. cit., Ref. 125, p. 1.

${ }^{132}$ G. Kubitschek, LEGIDA speech (2015): https://www.youtube.com/watch?v=Q6J7zjA81ps (accessed17 November 2017).

${ }^{133}$ IfS, op. cit., Ref. 125, p.1.

${ }^{134}$ Anticipating a national cultural death is common in the GNR and reflected in the titles of books such as Sarrazin's Germany Abolishes Itself, op. cit., Ref. 20, and Rolf Peter Sieferle's Finis Germania, op. cit., Ref. 19.

${ }^{135}$ IfS, op. cit., Ref. 125, p. 29.

${ }^{136}$ The Identitarian Movement was formed around the year 2002 and can be considered the GNR youth movement. It is present in several European countries and connected in a transnational network (for an analysis of the Identitarian Movement, see J. Bruns, Die Identitären: Handbuch zur Jugendbewegung der Neuen Rechten in Europa (Duisburg: Unrast, 2016).

${ }^{137}$ IfS, op. cit., Ref. 125 , pp. 8-13.

${ }^{138}$ M. Sellner, 'Heidegger, revolution, Querfront', Sezession Online (2015), available at: https://sezession.de/49665 (accessed 21 September 2017).

${ }^{139}$ IfS, op. cit., Ref. 125, p. 12.

${ }^{140}$ IfS, ibid., p. 9.

${ }^{141}$ IfS, ibid., p. 10.

${ }^{142}$ IfS, ibid., p. 12.

${ }^{143}$ Gessenharter, 'Intellektuelle Strömungen', op. cit., Ref. 11, p. 194; Gessenharter, Die Neue Rechte, op. cit., Ref. 12, p. 40.

144 cf. R. Beiner, 'The moral vocabulary of liberalism', Nomos, 34 (1992), p. 145.

${ }^{145}$ Skinner, Vision, op. cit., Ref. 8, p. 135.

${ }^{146}$ Sellner, 'Heidegger, revolution, Querfront', op. cit., Ref. 135, pp. 2-3.

${ }^{147}$ M. Heidegger, 'Nur noch ein Gott kann uns retten', interview with Heidegger from 1966, published posthumously in Der Spiegel 31 May 1976: http://www.spiegel.de/spiegel/print/d-41238349.html (accessed 14 March 2018).

${ }^{148}$ M. Lichtmesz, Kann nur ein Gott uns retten? (Schnellroda: Antaios, 2014), pp. 97-122.

${ }^{149}$ Lichtmesz, ibid., pp. 97-98. 
${ }^{150}$ Lichtmesz, ibid., p. 98.

${ }^{151}$ Lichtmesz, ibid., p. 98.

${ }^{152}$ Lichtmesz, ibid., p. 122.

${ }^{153}$ L. Jäger, 'Nach der Wahl', Tumult - Vierteljahresschrift für Konsesstörung, 04 (2017), p.7.

${ }^{154}$ T. Küchenmeister, 'Rasse - die unheimliche und verdrängte Wahrheit - Anmerkungen eines Ausstellungsbesuchers', posted on the Tumult Facebook page on 5 June 2018: https://www.facebook.com/TUMULTVierteljahresschrift/photos/a.525756317603284.1073 741828.525624937616422/912886612223584/?type=3 (accessed on 30/6/2018).

155 'Die Erfindung der Menschenrassen', Deutsches Hygienemuseum Dresden, 19 May 2018 - 6 January 2019.

${ }^{156}$ W. Bosbach, 'Der Begriff des Konservatismus ist heute nicht mehr positiv besetzt', Bibliothek des Konservatismus, 10 November 2014. Summary available at https://www.bdkberlin.org/veranstaltungsberichte/wolfgang-bosbach-sprach-ueber-das-schwierigeverhaeltnis-der-cdu-zu-den-konservativen/ (accessed 9 July 2018).

${ }^{157}$ W. J. Patzelt, 'Konservativ ist, patriotisch die gerechte Ordnung zu bewahren', Bibliothek des Konservatismus, 21 March 2018 Summary available at https://www.bdkberlin.org/veranstaltungsberichte/konservativ-ist-patriotisch/ (accessed 9 July 2018).

${ }^{158}$ T. Kunnas, Faszination eines Trugbildes: Die europäische Intelligenz und die faschistischeVersuchung 1919-1945 (Rohrdorf: Brienna, 2017).

${ }^{159}$ Summary available online: https://www.bdk-berlin.org/veranstaltungsberichte/das-herumirrenim-dschungel-des-faschismus/. I attended the presentation on 25 November 2017. The quotes are taken from my notes.

${ }^{160}$ T. Kunnas, Presentation in Italian online at: https://www.youtube.com/watch?v=67o_HxrJWM (accessed on 30 June 2017).

${ }^{161}$ According to Freeden's morphological approach to ideologies 'decontestation' is central to all ideologies and describes the attempt 'to end the inevitable contention by over concepts by decontesting them.' M. Freeden, Ideology: A Very Short Introduction (Oxford: Oxford University Press, 2003), p. 54.

${ }^{162}$ Gessenharter, 'Die "Neue Rechte” als Scharnier', op. cit., Ref. 12.

${ }^{163}$ Metapolitics is a concept elaborated by the French NR intellectual Alain de Benoist, which draws on Gramsci's theory of cultural hegemon; Taguieff, op. cit., Ref. 25, pp. 7-8. The focus of metapolitics is the realm of culture which is seen as the "infrastructural" basis of both civil society and the state', O'Meara, op. cit., Ref. 57, p. 65. Heidegger himself has used the term metapolitics in his earliest black notebooks to name what he hopes to be the 
'wholly other' that is to follow the end of traditional philosophy and metaphysics, M. Heidegger, Ponderings II-VI: Black Notebooks 1932-1938, trans. Richard Rojcewicz (Bloomington: Indiana University Press, 2016), p. 85; B. Rosenstock, Transfinite Life: Oskar Goldberg and the Vitalist Imagination (Bloomington: Indiana University Press, (2017), p. 116, footnote 77.

${ }^{164}$ Compact, 'Technik und Souveränität', Compact, 3 September 2014: https://www.compactonline.de/technik-und-souveraenitaet/ (accessed 30 June 2018).

${ }^{165}$ Compact, 'Populismus ist keine Ideologie, sondern ein Stil', Compact, 4 February 2018: https://www.compact-online.de/populismus-ist-keine-ideologie-sondern-ein-stil// (accessed on: 30 June 2018).

${ }^{166}$ M. Klonovsky’s blog, 9 September 2017: https://www.michael-klonovsky.de/actadiurna/item/643-9-september-2017 (accessed on: 3 July 2018).

167 'Sagen Sie mal Ernst Nolte...', on Klonovsky's blog, 19 August 2016: https://www.michaelklonovsky.de/artikel/item/302-sagen-sie-mal-ernst-nolte (accessed 3 July 2018).

${ }^{168}$ M. Jongen, Migration und Thymostraining. Presentation at the IfS on 17 February 2017: https://www.youtube.com/watch?v=cg_KuESI7rY (accessed on 15/3/2017).

${ }^{169}$ M. Jongen, ‘A Europa we can believe in', AGENDA. Der Informationsbrief der Bibliothek des Konservatismus, 8, August 2017, p. 8: https://www.bdk-berlin.org/wpcontent/uploads/2017/08/AGENDA-8_Online.pdf (accessed on 1 December 2017).

${ }^{170}$ M. Jongen, Nichtvergessenheit. Aus der Einleitung in das Theorieprojekt, 2009, p. 1: http://www.leopold-ziegler-stiftung.de/texte/50/marc-jongen-nichtvergessenheit-aus-dereinleitung-in-das-theorieprojekt (accessed 4 December 2016).

${ }^{171}$ Jongen, ibid., p. 1.

172 Jongen, ibid., p. 2.

${ }^{173}$ Jongen, ibid., p. 7.

${ }^{174}$ J. Bender and R. Bingener, 'Der Parteiphilosoph der AfD', Frankfurter Allgemeine Zeitung Online, 2016: http://www.faz.net/aktuell/politik/inland/marc-jongen-ist-afd-politiker-undphilosoph-14005731.html (accessed 11 December 2017).

${ }^{175}$ Bender and Bingener, ibid.

${ }^{176}$ J. Jessen and I. Mangold (2016) 'Man macht sich zum Knecht', Zeit Online, 9 June 2016: https://www.zeit.de/2016/23/marc-jongen-afd-karlsruhe-philosophie-asylpolitik (accessed on 5 December 2016).

${ }^{177}$ Weiß, op. cit., Ref. 11, p. 25. 
${ }^{178}$ Der Flügel, 2. Kyffhäusertreffen des Flügels. Germany, 2016:

https://www.youtube.com/watch?v=il1ZWHuM-yc (accessed 21 September 2017).

${ }^{179}$ Bender and Bingerer, 'Das wird man wohl noch aushalten dürfen', op. cit., Ref. 28.

${ }^{180}$ Zorn, op. cit., Ref. 73.

${ }^{181}$ F. Böckelmann, 'Vorwort', in B. Höcke and S. Hennig, Nie zweimal in denselben Fluss (Berlin: Manuscriptum, 2018), pp. 9-21.

${ }^{182}$ Höcke and Hennig, op.cit., Ref. 178, p. 77.

${ }^{183}$ Höcke and Hennig, ibid., p. 78.

${ }^{184}$ Höcke and Hennig, ibid., p. 121.

${ }^{185}$ Höcke and Hennig, ibid., p. 79.

${ }^{186}$ Höcke and Hennig, ibid., p. 127.

${ }^{187}$ Höcke and Hennig, ibid., p. 126.

${ }^{188}$ Höcke and Hennig, ibid., p. 129.

${ }^{189}$ Höcke and Hennig, ibid., p. 129.

${ }^{190}$ Höcke and Hennig, ibid., p. 194.

${ }^{191}$ For example, S. Matthay, 'Negotiating national identity: German intellectuals debate the 2015 migrant influx', The European Legacy 22(7-8) (2017), p. 770; T. Kroll and T. Reiz, Intellektuelle in der Bundesrepublik Deutschland: Verschiebungen im politischen Feld der 1960er und 1970er Jahre (Göttingen: Vandenhoeck \& Ruprecht, 2013).

${ }^{192}$ Skinner, Visions, op. cit., Ref. 8, p. 149. 